\title{
Transitivity and Critical Discourse Analysis on Emma Watson's Speech at the Launching of UN Women "HeForShe" Campaign
}

\author{
$1^{\text {st Roza Puspita }}$ \\ English Language Study \\ Sanata Dharma University \\ Yogyakarta, 55002, Indonesia \\ rozapuspita@gmail.com
}

\author{
$2^{\text {nd }}$ Condra Antoni \\ Informatics Engineering, \\ Batam State Polytechnic \\ Batam, 29461, Indonesia \\ condra@polibatam.ac.id
}

\begin{abstract}
This research focuses on the analysis of transitivity, social wrong and solving problem in Emma Watson's speech for the HeForShe campaign by using Fairclough's theoretical framework of critical discourse analysis. Transitivity analysis is the fundamental tool to see how Emma Watson using language to show people ideology of the issue and also assert her thought in the speech which elaborated in the Fairclough's steps methodology to find the social wrong, obstacle in solving the social wrong, the position of social wrong and the strategies to pas the social wrong. The results show that there are some issues that needs to be dealt with to achieve gender equality. Women and men need to be united because the impact of the gender inequality is not only for women but men as well. Redefinition of feminism hopefully can make people disassociate feminism with manhating ideology. The use of the public figure as the speaker is one of the effective way to highlight gender inequality issue and that seems controversial as it gets a lot of attention through social media
\end{abstract}

Keywords - campaign, Critical Discourse Analysis, gender inequality, transitivity

\section{INTRODUCTION}

Language is one of the tools to operate the power of ideology. In addition, language is included the domination of others by others. ${ }^{1}$ This statement is supported by Halliday that language is not only consists of sentences ${ }^{2}$, but also a text or discourse in which the exchange of intentions in interpersonal context between one another is existing. However the function of language as a tool of power is not always negative. It can also be used as the way to invite people to combat the negative power that people use. It can be seen in the campaign spoke by Emma Watson entitled "HeForShe".

Gender inequality is not a recent issue. It has been decades since women started fighting for gender equality, and the word feminism may come to mind when talking about gender equality. Feminism is defined as "the belief that men and women should have equal rights and opportunities related to political, economic, and social". Nothing about disregarding any other sexes is found in the definition of feminism; however, many believe that feminism is synonymous to man-hating.
Intentionally or unintentionally, many of us are actually feminists.

However, gender equality is still believed to be women's issue; that only women who are fighting for gender equality. This is what Emma Watson, a UN Women Goodwill Ambassador, wanted to stop. In her speech for the "HeForShe" campaign, she invited men and boys to be advocates for gender equality; that gender equality is not merely women's issue. Given the facts that young men also suffer from mental illness due to their fear of asking for help, shows that men are also still imprisoned by gender stereotypes. Through the speech, Watson intended to tell that both men and women should feel free to be sensitive and to be strong. The speech delivered a message about a uniting movement where men can be the "he" for "she" and to struggle together for gender equality.

In analyzing Watson's "HeForShe" speech, two theories are applied herein, i.e. the Transitivity Analysis Theory by Halliday and Fairclough's Theoretical Framework of Critical Discourse Analysis. Song defines Transitivity as a grammatical system that deals with different types of process which can be found in the language and the structure. ${ }^{4}$ The types of process include mental, material, relational, behavioral verbal and existential processes. In the structure, transitivity can function as a clause that represents experience. ${ }^{5}$ Furthermore, the writer also use the Theoretical Framework of Critical Discourse Analysis which was developed by Fairclough to see language as discourse and social practice, and how language, ideology, and identity interrelate to each other.

This paper aims at analyzing a speech by Emma Watson for the "HeForShe" campaign. Emma Watson is an actress whom famous for her movies "Harry Potter" as Hermione. The writer will discuss about the procedure on collecting the data as well as analyzing the data, and also discuss the result of the analysis, in the next sections. 


\section{METHODOLOGY}

The data of this paper that the writers analyze is taken from the speech delivered by Emma Watson when UN Women launched the campaign "HeForShe" in 2014. After selecting the Watson's speech as the data that will be analyzed, the writers selected important and relevant clauses and/or sentences from Watson's speech. After that, the writers put the clauses and/or sentences into the transitivity analysis table to analyze further using the transitivity analysis theory. The writers would not analyze all of the sentences in the speech, but only the selected ones. The clauses and/or sentences that were selected by the writers are the ones that are important and seem relevant to the study in this paper. The writers selected the clauses and/or sentences which show Watson's ideology of gender equality and her hopes for the future regarding the issue.

Following the data collection, the writers analyze the data. Using Halliday's Transitivity Analysis Theory, the selected clauses and/or sentences from Watson's speech were put in a transitivity analysis table to see what type of process occurs and to count the frequency of the processes occurrences in the speech. As mentioned before that the selected clauses and/or sentences contains Watson's perspective on the idea of gender equality, so through analyzing the language when delivering the speech, the writers interpret further how Watson feels and what she experiences about the issue of gender equality.

The next step that the writers did was analyzing the data using Fairclough's Theoretical Framework of Critical Discourse Analysis. Following Fairclough's four stages, the writers first of all focused on the social wrong, whether there are any social wrong spoken out by Watson in her speech regarding the issue of gender equality. The second stage was the writers identify if there are any obstacles to address the social wrong. The writers analyze semiotic and other social elements derived from the speech.

The third stage was considering whether or not the social wrong is needed in the society; if it does, then in what way is the social wrong needed in the society. The fourth stage was to identify whether there are any ways to overcome the obstacles by analyzing and presenting what might be Watson's ideas that are present in her speech.

\section{FINDING AND DISCUSSION}

Transitivity analysis has become the one of the medium to conduct CDA. In transitivity, what happen in the text can be showed? Based on transitivity analysis, most opinion utilized material and mental processes to show what Watson expect from people which then will be discussed in the four steps in Fairclough methodology.

\subsection{Transitivity analysis}

Four type transitivity processes are found in Emma Watson campaign. There are mental processes, material process, verbal and relational process. Mental processes are dominated in the speech and followed by material processes while verbal and behavioral are rarely used in the speech. The detail of the explanation will be described as follow.

\subsubsection{Mental Process}

Four type transitivity processes are found in Emma Watson campaign. There are mental processes, material process, verbal and relational process. Mental processes are dominated in the speech and followed by material processes while verbal and behavioral are rarely used in the speech.

Mental processes are dominated in the speech which used to describe psychological events, not action. Mental process needs two participants which are Senser and Phenomenon. ${ }^{6}$ The senser in the mental process is usually a human while the Phenomenon is as the participant that is thought, felt, or perceived by the conscious Senser. ${ }^{7}$ There are four types of mental process which are cognition, affection, volition, and perception. Based on the data from Watson's speech, three kind of mental processes can be found. The most dominated is mental process of cognition as can be seen in the table. Those are both the fact and also her though about what is being discussed. Besides mental process of cognition, the mental process of volition is giving back impact toward the issue which is gender inequality. The construction of mental process of volition in this speech is dominantly constructed through cognition. According to Halliday, projection actually shows how one clause relates to another. ${ }^{8}$ Through the data it can be seen that Emma Watson put a lot of effort to show her ambition to convince people that there are the facts that some problem of gender inequality happen and very crucial to be discussed to end this problem and inviting people to achieve it.

\section{TABLE I. MENTAL PROCESS}

\begin{tabular}{cll}
\hline No & \multicolumn{1}{c}{ Clause } & \multicolumn{1}{c}{$\begin{array}{c}\text { Type of } \\
\text { Transitivity }\end{array}$} \\
\hline 1 & We want to end gender equality & Mental Process \\
\hline 2 & $\begin{array}{l}\text { we want to try and galvanize as many men and } \\
\text { women as possible ... }\end{array}$ & Mental Process \\
\hline 3 & $\begin{array}{l}\text { the more I realized that fighting for women's } \\
\text { rights... }\end{array}$ & Mental Process \\
\hline 4 & $\begin{array}{l}\text { when at eight I was confused at being called } \\
\text { "bossy"... }\end{array}$ & Mental Process \\
\hline 5 & $\begin{array}{l}\text { I decided that I was a } \\
\text { as my male counterparts }\end{array}$ & Mental Process \\
\hline 7 & $\begin{array}{l}\text { I think it is right that I should be able to make } \\
\text { decisions about my own body }\end{array}$ & Mental Process \\
\hline 8 & $\begin{array}{l}\text { I think it is right that women be involved on my } \\
\text { behalf... }\end{array}$ & Mental Process \\
\hline 9 & $\begin{array}{l}\text { I think it is right that socially I am afforded the } \\
\text { same respect as men }\end{array}$ & Mental Process \\
\hline 10 & $\begin{array}{l}\text { I've seen young men suffering from mental illness } \\
\text { unable to ask for help... }\end{array}$ & Mental Process \\
\hline
\end{tabular}




\subsubsection{Material Process}

Material process is a process related to action. There are two participants involved in this process, those are actor and goal. Actor is the thing or the one which does the action while goal is the thing or the one which is on the receiving end of the action. ${ }^{7}$ There are some examples of the material processes in Watson's speech that can be seen in Table 2 .

TABLE II. MATERIAL PROCESS

\begin{tabular}{|c|c|c|}
\hline No. & Clause & Type of Transitivity \\
\hline 1 & $\begin{array}{l}\text { Today we are launching a campaign } \\
\text { called "HeForShe" }\end{array}$ & Material Process \\
\hline 2 & $\begin{array}{c}\text { I am reaching out to you because I need } \\
\text { your help }\end{array}$ & Material Process \\
\hline 3 & $\begin{array}{l}\text {-and to do what we need everyone to be } \\
\text { involved }\end{array}$ & Material Process \\
\hline 4 & $\begin{array}{l}\text {... for fear it would make them look less } \\
\text { "macho" }\end{array}$ & Material Process \\
\hline 5 & $\begin{array}{c}\text { We are struggling for a uniting word } \\
\text { but... }\end{array}$ & Material Process \\
\hline
\end{tabular}

In these examples, two actors are found in this speech. The first actor which is dominantly used in this speech is I is refers to the speaker and the actor which is not dominant is we which refers to speaker, UN women, and audiences. Those are the actors that carry the action.

Several Goals that the actors want to achieve in the speech can be seen in this material process. The result of action that the actors done which affect the center issue can be welldescribed through the words that used in this speech such as equality, the same rights, and opportunities. The Goal that are expressed in this speech is not only referred to the main objects who are women but also to the objects that are considered as the entities that are affected by the actions which are done by the Actor (S), such as men, women, and you. The goals are indicated not only for women but for men as well as the result of uniting to end gender inequality.

\subsubsection{Verbal Process}

Verbal processes are processes of saying and are expressed by verbs. ${ }^{7}$ In this process, there are three participants that can be involved, those are Sayer, Receiver, and Verbiage. Sayer can be anything that is able to put out a signal and Receiver is the one to whom the process is directed while Verbiage is something that is delivered which is in the form of noun. ${ }^{9}$

\section{TABLE III. VERBAL PROCESS}

\begin{tabular}{ccc}
\hline No. & Clause & $\begin{array}{c}\text { Type of } \\
\text { Transitivity }\end{array}$ \\
\hline 1 & the more I have spoken about feminism & Verbal Process \\
\hline 2 & I started questioning gender-based assumptions & Verbal Process \\
\hline 3 & sadly I can say that there is no one country... & Verbal Process \\
\hline 4 & $\ldots$ and to ask yourself if not me, who? If not & Verbal Process \\
& now, when? & \\
\hline
\end{tabular}

Through verbal process Watson shows the theme in the speech that she has been discussed, the information that she has given and the message that she has been delivered to people is related to feminism. By saying "have spoken" the action about the theme is already done. She indicates that this theme has told not only just one time but several times.

\subsubsection{Relational Process}

Relational process is the process of being which have two modes; attributive and identifying process. ${ }^{7}$

\section{TABLE IV. RELATIONAL PROCESS}

\begin{tabular}{ccc}
\hline No. & Clause & Type of Transitivity \\
\hline 1 & $\begin{array}{c}\text { feminism by definition is the } \\
\text { belief that men and women } \\
\text { should have equal rights and } \\
\text { opportunities }\end{array}$ & Relational Process \\
\hline 3 & that I was a feminist & Relational Process \\
\hline 3 & $\begin{array}{c}\text { there is no one country in the } \\
\text { world where all women can... }\end{array}$ & Relational Process \\
\hline 4 & $\begin{array}{c}\text { If you believe in equality, you } \\
\text { might be one of those inadvertent } \\
\text { feminists I spoke of earlier }\end{array}$ & Relational Process \\
\hline 5 & gender equality is your issue too & Relational Process \\
\hline 6 & $\ldots$ we have a uniting movement & Relational Process \\
\hline & &
\end{tabular}

Both modes in the relational process can be found in the speech. The first example is when Watson uses attributive to classify herself as feminists. This can be seen from the participants that are involved in the process which are connected by verb to be. It connects $I$ as the Carrier and $a$ feminist as the Attribute. Another clause that use identifying process can be found in the second and third example where Watson talks about feminism is associated with man-hating she identifies about feminism and the definition of definition by herself.

\section{Fairclough four steps methodology}

As analysis of transitivity is the fundamental tool in conducting CDA. Based on the data, there is a problem that can be identified through the use of the language by Emma Watson. The problem and the probability in solving it will be discussed in these four step by Fairclough below.

\subsubsection{Social wrong}

The social wrong introduced by Emma Watson in her "HeForShe" campaign is gender inequalities which are contributed in these three categories (1) about the necessity of the feminist movement (2) the miss depiction of feminist term in the society (3) the victims and protectors of the impact of the gender inequality. 
Many of the clauses that categorized as material process (Table 2) show Watson's action to encourage people to realize that it is necessity for people to have feminist movement. From the text showed how Emma Watson does a campaign because gender inequality is still a big issue all over the world. She introduce some problems that faced by the women in order to get their right. How in this world women is depicted as the second class. She is creating on how feminist movement is necessary to end the misery of the women.

Watson used her experience to build the necessity for the feminism. Having experiences called as bossy girl just because she wanted to direct a play, getting sexual abused by the press and also her girl friends started to dropping out from the sport team because they didn't want to be appear "muscly". These problem shows that there is gender violence experienced by Emma Watson. Nasri stated the violence experienced by women not only in the form of physical attacks ${ }^{10}$, but also in the form of attacks against psychological trauma resulting. She also explain thinks about women getting their right to be equal as men in her statement that show as mental process. She uses the term women's right. She wanted to emphasize that women need to get the right as the human. In this case she gives the example of respect and authorization as the human as the movement that need to be fight for as the human right.

Through the action she has done as being feminist, she understands that feminist is not well defined by the society. The negative portrayal is always attached to women. Besides being the second class human, when women struggle for the equality they are also seen as the man-hating people, they see the aggressiveness of the women. The society constructs created position of women as an essence that cannot be changed. ${ }^{10}$ Women is always seen as the loser in the society. Watson realizes that there is misconception of the term feminism in the society. McRobbie writes about how young women are afraid and avoid the feminist term because it is associated with anger and bitter man-hatter. ${ }^{11}$ Basically, the issue of feminism is not a recent issue but still there are many people that have misunderstanding with the goal of the feminism. Stated from Watson speech, there is still big indication that people think feminism is anti-men, man-hating, and aggressiveness of the women to degrade men.

Watson in the beginning of the speech introduces the listener the definition of the feminism: "the belief that men and women should have equal rights and opportunities". The first goal of the feminism is actually to get to be equal as a man. Starting from the first wave feminism up to now the goal is always about being equal. The miss depiction of the term can be affected in achieving the goal. Therefore, since the beginning it is important for Watson to clarify the definition of the feminism. Seeing that feminism is the crucial term to be defined in order to represent that the ideology of the feminism is not about degrading men but it is useful for the benefit of the both sexes.

Gender inequality's victims and protectors I've seen young men suffering from mental illness unable to ask for help...

... for fear it would make them look less "macho"

I've seen men made fragile and insecure by a distorted sense of what constituents male success

In these statements, it is very well described as mental process how the participant feels about the condition of the environment. Through her speech Watson depicts that the victims of the gender inequality is not only women but men as well. Women are underestimate as human being who are very difficult to gain the authority of herself, gain the opportunity to be the same organization and get the same amount of salary as men, gain respect from people, while men without consideration is actually also facing a problem like difficulty of asking for help especially for the women. The way men look is more important than what they feel, sacrificing and been bullied in the school just because of less macho than other men. They try hard to be looked very masculine because the patriarchal system that still holds by people in some part of the worlds.

\subsubsection{Obstacles to address social wrong}

McRobbie explains in her book that the idea of the protection of the women actually already adopted by the government, organization and politician, there for the need of the feminist movement asked by Watson in the first idea in achieving gender equality is not a valid action. ${ }^{11}$ However, Watson in her speech can show the representation in which the necessity of the feminism as very necessary. The patriarchal ideology is still held by several people that believe men are in higher position than women. However obstacles in solving this gender inequality are clearly stated in the speech. Achieving gender equality will be very difficult because of two reasons based on the speech.

Based on the perspective of the meaning feminism term that is understood by people. In this speech, it is clearly stated people tend to associate the word feminism with man-hating or where women try to beat or be better than men. They see aggressiveness of the women in order to tackle man power. This chaotic situation by having this perspective, this definition makes not only men are afraid but also the women are afraid to be called as feminist. This situation make women 
do not want to fight for gaining their right to be as equal as men. Women tend to accept the condition rather than fight for being equal.

Before clarifying the definition of the feminism, Watson first depict the idea of feminism by several people in the clause (a) Watson as the senser show the verb phrase portrays the meaning of feminism and the goal of the feminism as the manhating activity. The idea of being and supporting feminism is seen as actions that related to radical things and it is seen as too rebellious or even against men in so many ways by several people that makes people afraid to be a feminist. However, Emma Watson tried to tackle this negative ideas toward her speech. Moreover to give the public more correct view about feminism, through relational process in clause 2 , she defined feminism as the belief that men and women should have equal rights and opportunities (the Value), which it is as a representation of gender equality. Thus, it can be assumed that Emma Watson supports feminism and wanted people to have positive views of the feminism as well.

Patriarchal ideology from men point of view can be seen clearly in these two statements in Watson's speech. The feminist movement that asks for the equality hardly be achieved because of the men's thought about Masculine Hegemony. In her speech, Watson gives an example that as clauses below:

(a) I (Senser) have seen (Mental Process: Perception) young men suffering from mental illness (Phenomenon),

(b) for fear (Circ: Cause) it (Actor) would make (Material Process) them (Goal) less "macho". Men are afraid and suffering to ask for help especially to women. This shows how men really holds the ideology that they will be seen as the weak person if the ask for help because the one that always ask for help is always women in patriarchal perception. By adopting this gender stereotype gave the portrayal of men with their quality and power, yet here Emma Watson communicated her observation through mental process which utilizes the action word have seen, if really these stereotype are what cause men wound up under strain. This also makes men impossibly wanted to be equal as women. This stereotype is the big obstacle for women in patriarchal system to have the same rights, opportunities and respects as men get.

\subsubsection{The position of social wrong}

Gender inequality is something that both men and women want to abolish. People are trying hard to have the equality for all part of society in all aspects of life. For decades the equality is just the fight of the women as we can be seen in the third wave of feminism in the Peter Barry's book that men still didn't want to be equal as women. Not to mention, as women writers, they didn't have their language to write it was considered as men language.

Today, it is different. There are many movements that ask for gender equality is lead by men. As stated in the UN page that a lot of man initiates to speak about gender equality and become feminism.

\subsubsection{Strategies to pass the obstacle}

The advantage of the Watson power as the young famous beautiful and talented actress to influence people not only young generation but also old people to understand the discrimination of women and men as well because of the gender inequality. UN Goodwill organization use the very good way by having Emma Watson as the speaker rather than having an expert in the feminism. It will probably better deliver than Emma Watson if the UN organization has an expert or researcher or politician in giving speech. However Watson's influence is bigger than them. As information, As a British actress who is very well-known through her strong character in one of the biggest influential movie which is Harry Potter, certainly she has received a lot of attention from people all around the world. What she says in the speech will get a lot of attention from people. The impact of having this privilege can be seen after her speech in United Nation was posted in many social media the day after the event was held. People started to talk about the topic in her speech. Many pros and contras are talked about her definition of feminism in the social media. Her speech has become very controversial. It means by having Emma Watson as the UN representation to highlight the gender equality is one of the best strategies to get people attention.

Emma Watson strategy to achieve gender equality has begun when she explains the word feminism is no longer about a movement which is only supported and done only by women for women's necessity, Unity is another idea that can be found through the transitivity processes which are used by Emma Watson.

Seeing the history of the feminism where women do not want to have any form of oppression from men, or being the second class of human, women start fighting for their right yet it is not yet fully supported by women. There is still a stigma that thought feminism is meant as positioning men lower than women which impact toward the fear of the women to fight for their right. By having this campaign Watson invites all the women to actively participate in the feminist movement which have clearer goal. The goal is to have gender equality not beat the men. Beating the men is by definition to lower men's position or to make women become more superior to men. Here, clarification of feminism and the goal of feminism by 
Watson hopefully affect to all people in all over the world that actually there is no need to have superiority to differentiate people.

After having the clarification of the term feminism Watson and ask women to fight for her right Watson also introduces another significance way in achieving the equality between man and women. She portrays that the victims of having gender stereotypes can be affected to men as well. She gives some examples of the oppression that men have just because this stereotype. (it can be seen in the table 1). By having these problems Watson claims that actually this issue is men issue too. Therefore she asks men to fight together with women to erase all the kind of oppression. She asks men to unite with women to have a freedom. Men can ask for help to everyone without considering their status. Men can express their feeling without any label as identified as women. By having these two ways Emma Watson believes that gender equality as the goal of feminism can be achieved and there is no label anymore toward men and women. The real freedom for all human can be achieved.

\section{CONCLUSION}

The girl's and women's suffering being discriminated is the idea of the gender inequality for the previous era; today it is not only women who suffer from this inequality but men as well. Emma Watson in her campaign HeForShe has shown her sympathy toward this issue. Through her speech, start voicing out that being feminist does not mean having bad relationship with men or compete with men. The speech depicts an ideology through language use consist of demand of change. Watson has explained the word feminism into positive ideology.

This paper uses Fairclough's theoretical framework of CDA. The analysis uses four stages; 1.Focusing on social wrong 2.Identifying the obstacles to address the social wrong 3. Considering whether the social order needs the social wrong and 4.Identifying possible way past the obstacles. In the first stage of analysis, it is found that social wrong is about gender inequality. The second stage presents the obstacles to tackle the social wrong. There are two obstacles which are being feminist is seen as the radical action and men point view that still believe in masculinity hegemony. The analysis in stage three, the last stage of analysis is proposing strategy to tackle the obstacles. Watson in her speech propose that gender equality can be achieved if all part of the community men and women can work together to achieve that goal as being feminist. This stage above is proven by using linguistics feature by implementing Systemic Functional Grammar (SFG) theory.
Through some of her statements, there are three points that can be considered as solution of the problem reflected on the transitivity processes which are used by Emma Watson, those are about feminism, gender equality, and unity. By using different kinds of transitivity process, Emma Watson brought new positive thought about feminism that it is related to fight for women's rights and gender equality, and both are important things to be achieved. In proposing her new and clear definition of feminism, she emphasized about unity that refers to the case if men and women should support and work together in achieving equal rights and opportunities because gender inequality is no longer women's problem only. The ideologies are created to fulfill the purpose of the "HeForShe" campaign. It is to influence people so that they give their sympathy and support so then achieving "Gender Equality" is not justa dream.

\section{ACKNOWLEDGMENT}

Thank you to Mrs. Dra. Novita Dewi M.S., M.A. (Hons.), $\mathrm{Ph} . \mathrm{D}$ and the other members of Literature stream of English Language Studies Universitas Sanata Dharma Yogyakarta for their help providing motivating the researcher to finish her research.

\section{REFERENCES}

[1] N. Fairclough, Language and Power (Routledge, New York, NY, 2013).

[2] M. Halliday, Language as Social Semiotic (Edward Arnold, London, 1979).

[3] L. Tyson, Critical Theory Today (Routledge, NewYork, NY, 2006).

[4] Z. Song, Transitivity analysis of A Rose for Emily. Theor. Pract. Lang. Stud. 3(12) (2013) 2291-2295. https://doi.org/10.4304/tpls.3.12.22912295

[5] M. O'Donnell, (2011, November). Retrieved December 2018, from Language Function Cognition: http://web.uam.es/departamentos/filoyletras/filoinglesa/Courses/LFC11 /LFC-2011-week3-Transitivity.pdf

[6] L.Schinke-Llano, Reviewed work: Functional English grammar: An introduction for second language teachers. Mod. Lang. J. 81(3) (1997) 419-420. https://doi.org/10.2307/329324

[7] G. Lock, Functional English Grammar, 3rd ed. (Cambridege University Press, New York, NY, 1997)

[8] S. Eggins, An Introduction to Systemic Functional Linguistics, 2nd. ed. (Bloomsbury Academic, London, 2004).

[9] S. M. Hemas, Transitivity and ideology in Emma Watson's speech for the "HeforShe" campaign, Language Horizon 1(1) (2016) 0-11.

[10] D. Nasri, Ketidakadilan gender terhadap perempuan dalam novel Padusi karya Ka'Bati, Madah: Jurnal Bahasa Dan Sastra 7(2) (2018) 225. https://doi.org/10.31503/madah.v7i2.431

[11] social change. from http://booksdescr.org/item/index.php?md5=2A748DD6617EE57FB737 05B03AA59 
